УАК 316.75:32(470)

ББК 66.05(2Poc)

DOI 10.22394/1682-2358-2017-5-12-19

I.I. Sanzbarevsky, Doctor of Sciences (Politics), Professor of the Public Administration Department, Tambov Branch of the Russian Presidential Academy of National Economy and Public Administration

\section{THE NATIONAL IDEA AS A SUBJECT TO THE POLITICAL COMPETITION IN MODERN RUSSIA}

The danger of the temptation to replace the national idea by a social, religious, economic or political ideology is considered. Political transformations of the epoch of the Russian Empire and the Soviet Union are analyzed. Conclusions are drawn on the necessity of the compliance with the social commute on the principles of state structure that is essentially the basic declaration of the national idea of contemporary Russia.

Key words and word-combinations: national idea, ideology, political competition.
И.И. Санжаребский, доктор политических наук, профессор кафедри государственного и муншиипального управления Тамбовского филиала Российской академии народного хозяйства и государственной службь при Президенте РФ (email:sanzigor@yandex.ru)

\section{НАЦИОНААЬНАЯ ИАЕЯ \\ КАК ОБЪЕКТ \\ ПОАИТИЧЕСКОЙ \\ КОНКУРЕНЦИИ \\ В СОВРЕМЕННОЙ РОССИИ}

\begin{abstract}
Аннотация. Рассматривается опасность подмены национальной идеи какой-либо социальной, религиозной, экономической или политической идеологией. Анализируются политические трансформации эпох Российской империи и Советского Союза. Делаются выводы о необходимости соблюдения общественного договора о принципах государственного устройства, являющегося по своей сути основополагающей декларацией национальной идеи современной России.

Ключевые слова и словосочетания: национальная идея, идеология, политическая конкуренция.
\end{abstract}

C мысловое значение используемого в статье понятия «национацьное» заключается в том, что нация рассматривается как политическое сообщество гражкан одного государства, отличающихся общегражданским самосознанием (например, американцы, британцы, испанцы, китайцы, мексиканџы, россияне (русские)), рефлексией общей исторической суАьбы и еАиного кумьтурного наслеАия, ремигиозной толе- 
рантности, как национальная государственность [1]. Современное смысловое значение наџии (национальное) не следует отождествлять со сложившимся в России ХХ в. определением национальности (этнического) [2] .

Принимая участие в работе межкаународного дискуссионного клуба «ВалАай», Президент РФ В.В. Путин отметил: «Россия испытывает не только объективное Аавление глобализации на свою наџиональную идентичность, но и последствия наџиональных катастроф XX в., когда мы дважды пережкили распад нашей государственности. В результате получили разрушительный удар по культурному и Ауховному коду нации, столкнулись с разрывом традиций и единства истории, с деморализаџией общества, с дефиџитом взаимного Аоверия и ответственности. Именно в этом многие корни острых проблем, с которыми мы стацкиваемся. ВеАь вопрос ответственности переА самим собой, обществом и законом - один из основополагающих не только в праве, но и в повсеАневной жизни» [3] .

ОАним из интересных результатов современного исследования вопросов, связанных с наџиональной илеей, явцяется комлективная монография, выполненная в Центре проблемного анациза и государственно-управленческого проектирования под редакцией авторского совета в составе В.И. Якунина, С.С. Сулакшина, В.Э. Багдасаряна, М.В. Вилисова, С.Г. Кара-Мурзы, В.Н. Аексина. В ней предложен интересный Аискурс мультидисциплинарного научного подхода, в котором отражается, с одной стороны, современный факт обязательной фиксаџии наџиональной идеи в нормативно-правовых актах государства (прежде всего Конститущии РФ), а с Аругой - ее рефлексирующая изменчивость, характерное время которой измеряется поколени-

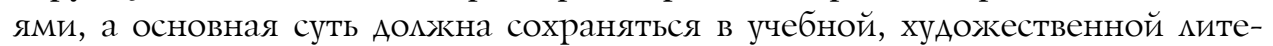
ратуре, иных произведениях искусства. ОАнако при этом в вводной части исследования акцентировано внимание на том, что, «глядя на современную российскую Конституџию, сказать, что у России есть наџиональная идея нельзя, поскольку эта Конституџия ее прямо запрещает, именуя в ст. 13 государственной идеологией» $[4$, с. 16] .

Четкость рефлексивной формулировки национальной идеи в авторитарном режиме правления Российской империи, которая подкупает своей $а$ коничностью и сегодня, весьма емко была выражена в формуле министра образования С.С. Уварова «Православие, самодержавие, народность». Еще более понятное и могичное звучание Аля подАанных русского царя она получима в Аевизе служения Родине - «За веру, царя и Отечество! [5], который быц понятен не только православному соцдату, но и иноверџу, например правоверному мусульманину. Рефлексия советского периода истории нашиа свое выражение в том, что царь стал тираном, вера - опиумом народа, а отечество перестало быть Российской империей и стало Союзом Советских Соџиалистических Республик, в котором вроде так же все стало понятно идеологически - от диктатуры пролетариата к Аевизу «Пролетарии всех стран, соеАиняйтесь», «САужу трудовому народу!», затем «САужу Советскому Союзу» и «Вперед к победе коммунизма». Монополия на 
«ум, честь и совесть эпохи» «руководящей и направляющей симы» советской политической системы была идейно подорвана в 1981 г., когда наступимо обозначенное в 1961 г. на XXII съезде Коммунистической партии СССР время построения коммунизма [6], а он не наступил. ИАеологическая коммунистическая монополия при формулировании наџиональной идеи перестает де-факто быть таковой. Право определения общенациональных ценностей и моделей развития становится преАметом политической борьбы, идеологической, внутригосударственной, внутринациональной, а также межэтнической конкуренции. «Новая историческая общность - советский народ", заявленная в Конституции СССР 1977 г. [7], проявияа в 90-х годах XX столетия как этническую, так и национальную самоидентификацию, и на карте мира вместо Советского Союза образовались самостоятельные нации, независимые государства по числу советских респубцик, у которых возникма объективная историческая потребность формулировки своих национальных идей.

Аелая определенные выводы из политических трансформаций ХХ в., отметим, что отождествление идеологии строительства коммунизма с идеей российской государственности в советский периоА, а также идеей государственности с религиозной идеологией в конџе имперского периода сыграли не последнюю роль в развитии трагических событий в России начала XX в. В настоящее время мы продолжаем наблюдать активное стремление ряда политических, соџиальных идеологий на исключительное право навязывания себя в качестве нащиональной идеи и основополагающей модели развития с вариативностью от анархизма до монархизма, от миберализма до тоталитаризма, от частной собственности до ее полной миквидации и построения коммунизма. При этом перечень существующих теорий, которые пытаются претендовать на роль не только общественной, но и государственной идеологии, не ограничивается подобными вариаџиями. Интересные комментарии об этом даны в труде Ажеймса Скотта о «бцагих намерениях государства, или почему и как проваливались проекты улучшения условий человеческой жизни» [8] .

Таким образом, в настоящее время предметность как внутринациональной, так и глобальной политической конкуренции определяется рефлективностью отражения национальных ценностей и права формулирования модемей развития. Основной опасностью Аля государственности явцяется искушение тенденцией государственной идеологизации, связанной с современными дискуссиями по поводу ст. 13 Конституџии РФ, подмены наџиональной идеи какой-цибо соџиальной, религиозной, экономической или политической идеологией [4]. Иейтмотивом президентского выступления в международном дискуссионном клубе «Вамдай» стали слова: "Аля россиян, дия России вопросы “кто мы?”, “кем мы хотим быть?” звучат в нашем обществе все громче и громче. Мы ушли от советской идеологии, вернуть ее невозможно. Приверженцы фундаментального консерватизма, идеализирующие Россию до 1917 г., похоже, так же далеки от реальности, как и сторонники западного ультралиберализма.

14 Bulletin of the Volga Region Institute of Administration • 2017. Vol. 17. № 5 
Очевидно, что наше движение вперед невозможно без духовного, культурного, национального самоопределения, иначе мы не сможем противостоять внешним и внутренним вызовам, не сможем добиться успеха в условиях глобальной конкуренции» [3] .

Рассуждая о кардинальных трансформаџиях российской государственности в XX в., ряд исследователей считают их «распадом» и наџиональной катастрофой. Сосредотачиваться на эмоџиональной рефмексии, на том, что «возникшее в результате распада Союза и рыночных реформ российское общество расколото как никакое Аругое», и что мы построили самый хуАший вариант капитализма [9], при рассмотрении такой темы, как наџиональная идея, на наш взгляА, явцяется методологической ошибкой. Так Араматизировать нельзя, это надо считать скорее трагедией, но не катастрофой, поскольку историческая идентичность государственности не была утеряна. Государственность как традищия и наџиональная идея нашла свое выражение в практической реализаџии принџипа конституџионализма. Необходимо отчетливо понимать, что «национальная идея материализуется, становится Авижущей силой развития в том случае, если она мегализована в законе и цегитимирована в народном сознании. Национальная идея, объединяющая различные соџиальные, религиозные, политические идеологии и модели развития, всегда имеет государственное выражение. Как выживание, так и прогрессивное развитие мюбого наџионального сообщества в истории, как показывает практика, и в современном мире возможно только в пределах государственности» [10]. В связи с этим консерватизм, устойчивость, стабильность национальной идеи, апемлируя к мнению Президента РФ, находит свое выражение в том, что «суверенитет, самостоятельность, цемостность России безусловны. Это те “красные минии”, за которые нельзя никому заходить. При всей разниџе наших взглядов дискуссия об идентичности, о наџиональном будущем невозможна без патриотизма всех ее участников» [3] .

При этом отметим, что, как никогАа в отечественной истории, наиболее важной составмяющей национальной идеи явмяется суверенитет мичности. По своей сути современная конституция есть практическая реализаџия концепции общественного договора, объясняющая происхождение гражАанского общества, государства и права как результат соглашения между Аюдьми. Сутью мегитимаџии демократического режима правления является признание государственной властью прав и свобод не господствуюшего большинства ици меньшинства, а права каждого чемовека, гражданина пубАично конвертировать добровольное ограничение своей свободы во властный ресурс [11].

В России проявление конституционализма в формулировании национальных идей можно отнести к ранним проектам, именуемым «Кондиџии», и предложенным в 1730 г. будущей императрице Анне Иоанновне. Они были связаны с попыткой оформить общественный договор и ограничить самодержавие в правовых нормах [12]. Аля первой половины XIX в. характерно 
появление не только проектов конституџионного переустройства Российского государства, но и утверждение Основных законов Российской империи (1832). Интересны попытки конституционного оформления наџиональной идеи России начала XX в., когда бымо принято большое число конститущионных документов: Манифест от 17 октября 1905 г. «Об усовершенствовании государственного порядка», акты о Государственной думе, Государственном совете и Совете министров. 23 апреля 1906 г. появилась новая редакщия Основных законов Российской империи [13].

Политическая ангажированность разработанных в советское время конституционных документов (Аеклараџия прав народов России, Аеклараџия трудящегося и экспиуатируемого народа, Конституџии 1918, 1925, 1936 и 1977 гг.) отвечала на рефмексию общественного запроса на коммунистическую идеологию. В историю конституционного правосознания внесла свой существенный вкцаА обновленная Россия, приняв Аеклараџию о государственном суверенитете РСФСР, Федеративный договор, Конституџию Российской Федераџии 1993 г.

РассужАая о развитии современной российской государственности, необходимо констатировать ряд фактов политической рефлексии о том, что национальная идея российской государственности, при объявлении в 1993 г. всему миру России правопреемниџей СССР, наслеАниџей Российской империи, продемонстрировала свою состоятельность. Сохранив исторические традиции, страна приобрела мегальные международные права на наследие Российской империи, рассчиталась с Аолгами царской России. По отношению к населению Советского Союза, в отличие от Аругих стран бывших союзных республик СССР, Россией были выдержаны все гражданские обязательства. Например, граждане СССР жили и работали в современной России на основе советского гражданства и добровольно принимали российское; советские военнослужащие не принимали новой присяги Российской Федераџии, а продолжали служить России, принеся ее однажды со словами «САужу Советскому Союзу», принимали новую присягу только поступающие на скужбу.

Аругая, не менее важная сторона современной политической рефлексии, закцючается в том, что наџиональная идея находит свое знаковосимволическое выражение как в государственной символике, так и в символике ее силовых структур. К примеру, герб и фмаг современной России символизируют преемственность с историей Российской империи, а музыка современного гимна - это гимн Советского Союза со словами, посвященными России. При этом современная российская герацьдика впитывает героические традиџии как советского, так и имперского периодов истории. В 2014 г. весь мир отметил 100-летие Первой мировой войны. В настоящее время 1 августа в России учрежден как Аень памяти воинов, погибших в Первой мировой войне, в составе Вооруженных сил России возрождены прославленные Семеновский, Преображенский полки. На Параде Победы в еАином строю иАут полки с петровской, советской и 
современной символикой, герои России, Советского Союза и наследники георгиевских кавалеров.

Важной стороной Аля современной политической рефмексии провозглашенного Конститущией РФ идеологического многообразия, заложенных в ней принципов толерантности межАу политическими, соџиальными, религиозными идеологиями (правовое, светское соџиальное государство), явцяются реальные условия дмя социально-политического проџесса функционирования национальной идеи как пропорџиональной сбалансированности ценностей, идеологий и моделей развития. При этом, если невозможна толерантность «по убеждению», то государство гарантирует толерантность «по принуждению». Это и есть то практическое воплощение наџиональной идеи, которое минимизирует возможности ее подмены какой-либо одной идеологией. Устойчивому состоянию пропорџиональной сбалансированности способствует политическая модель, в основу которой положкена республиканская форма правления во главе с президентом, функционирующая в демократическом помитическом режиме.

ЗАоровая соџиально-политическая конкуренщия идеологий всегда связана с существованием такого качества политического проџесса, как оппозиционность, но бывает, что «слишком часто в наџиональной истории вместо оппозиции власти мы сталкиваемся с оппозицией самой России... И мы знаем, чем это заканчивалось - сносом государства как такового. У нас практически нет такой семьи, которую бы обошли стороной беды прошлого века. Вопросы оџенки тех или иных исторических событий до сих пор раскалывают страну и обшество. Мы должны залечить эти раны, восстановить целостность исторической ткани. Нельзя больше заниматься самообманом, вычеркивая неприглядные или идеологически неудобные страницы, разрывая связь поколений, бросаясь в крайности, создавая или развенчивая кумиров. Пора прекратить замечать в истории только плохое, ругать себя больше, чем это сделают мюбые наши недоброжелатели. Критика необходима. Но без чувства собственного достоинства, без цюбви к Отечеству эта критика унизительна и непродуктивна. Мы должны гордиться своей историей, и нам есть чем гордиться. Вся наша история без изъятий должна стать частью российской идентичности. Без признания этого невозможно взаимное доверие и движение общества впереА», - отмечает Президент России [3] .

Конкурентная идеологическая среда является основной миберальной ценностью, на основе которой выкристамлизовывается содержание национальной идеи. Сегодня как никогда следует понимать, что национальная идентичность не может быть навязана сверху, национальная идея не может быть построена на основе идеологической монополии. Такая навязчивая монополия делает уязвимой государственность и неустойчивой всю политическую общественную конструкцию.

В современной России принята Концепция нового учебно-методического комплекса по отечественной истории [14], включающего в себя историкокультурный стандарт, позволяющий снизить эмоџиональное влияние по- 
митической рефмексии подмены наџиональной идеи какой-либо сощиальной, религиозной, экономической или политической идеологией. Стандарт содержит принџипиальные оџенки ключевых событий прошлого, основные подходы к преподаванию отечественной истории, сопровождается перечнем «трудных вопросов истории», которые вызывают острые дискуссии в обществе, а Аля многих педагогов и ученых - объективные сложности в преподавании и конџептуальном осмыслении прошлого, анализа настоящего и видения будущего. Именно сегодня научному сообществу от государственников до анархистов, от консерваторов до прогрессистов, от сторонников Аиктата Ао Аибералов, от «неославянофимов» Ао «неозападников», всему обществу преАстоит совместно работать наА поиском и формулированием общенаџиональных принџипов развития, рассматривая историческую преемственность как политическую трансформаџию российской государственности от Руси к Российской империи, через «Великую русскую револющию» к Советскому Союзу, и от Советского Союза к современной России.

Отвечая на «трудные вопросы» истории, мы отвечаем на вызовы как глобальной, так и внутринациональной политической конкуренции, решаем задачу наџиональной самоидентификаџии, укрепляем фундамент общественно-политической конструкции. Истинная политическая мудрость состоит в том, чтобы исправцять, а не уничтожкать прежние институты. Э. Бёрк цюбиц повторять крылатое выражение о том, что «история без политической науки бесплодна, а политическая наука без истории безродна». «Мой ведущий принџип реформаџии государства, - подчеркивал Бёрк в письме, аАресованном члену Французской ассамблеи, - использовать имеющиеся материалы... Ваши же архитекторы строят без фундамента» [15]. Консерватизм традиции госуАарственности и суверенитета, основывающийся на миберальных ценностях, есть самый надежный авторитет, ибо в нем находит свое воплощение «колмективная мудрость человеческого рода».

Это значит, что каждый раз, когда возникают рефмексивные попытки поставить под вопрос вековую многонаџиональность российской государственности, манипумяџии темой русского, кавказского, татарского, сибирского и еще какого- ибо другого национализма и сепаратизма, задающих вектор самоуничтожения культурно-исторического кода России, необхоАимо еще раз внимательно прочитать Конститущию России, ее преамбуму, в которой закреплена идея многонациональности народа Российской ФеАераџии, его соеАиненности общей судьбой на своей земле, приоритетности прав и свобод человека, гражданского мира и согласия, сохранения исторически сложившегося государственного единства, общепризнанности принципов равноправия и самоопределения народов, почитания памяти предков, передавших нам мюбовь и уважение к Отечеству, веру в добро и справедливость, незыбцемости суверенной государственности России и ее демократической основы, благополучия и проџветания России как части мирового сообщества, основанного на ответственности за свою Родину пе- 
ред нынешним и будущими поколениями [16]. Прочитать и понять, что надо просто соблюдать принятый нами формализованный общественный Аоговор о принџипах государственного и общественного устройства, являющегося по своей сути основополагающей деклараџией наџиональной идеи современной России.

\section{Библиографический список}

1. Новая философская энциклопедия: в 4 т. / председатель науч.-ред. совета В.С. Степин. 2-е изд., испр. и доп. М., 2010.

2. Большая советская энциклопедия. М., 1969-1978.

3. Путин В.В. Выступление на заседании международного дискуссионного клуба «Валдай». URL: www.kremlin.ru/news/19243

4. Национальная идея России: в 6 т. / В.И. Якунин, С.С. Сулакшин, В.Э. Багдасарян [и др.]. М., 2012. Т. 1.

5. Доклады министра народного просвещения С.С. Уварова императору Николаю I (публ. и коммент. М.М. Шевченко) // Река Времен. Книга истории и культуры: в 5 кн. М., 1995. Кн. 1. С. $68-78$.

6. Материалы XXII съезда КПСС. М., 1961.

7. Конституция (Основной закон) Союза Советских Социалистических Республик (принята на внеочередной седьмой сессии Верховного Совета СССР девятого созыва 7 окт. 1977 г.). URL: base.garant.ru/1549448

8. Скотт Дж. Благими намерениями государства. Почему и как проваливались проекты улучшения условий человеческой жизни / пер. с англ. Э. Гусинский, Ю. Турчанинова. M., 2011.

9. Попов Н.П. Востребована ли в России национальная идея? // Мир измерений. 2009. № 11. C. 47-55.

10. Санжаревский И.И. О российской конституционности и национальной идее (к 20-летию Конституции Российской Федерации) // Политическое управление: научный информационно-образовательный электронный журнал. 2013. № 2. URL: www.политуправление.pф/ arhiv/2013/02/sanzharevskiy.pdf

11. Санжаревский И.И. Инверсионно-ресурсная модель политической власти: демократия как политический режим конвертации ресурсов во власть // Вестник Поволжского института управления. 2016. № 4 (55). С. 4-9.

12. Кравеи И.А. Формирование российского конституционализма: проблемы теории и практики: дис... д-ра юрид. наук. Екатеринбург, 2002.

13. Яикова А.П. Основные государственные законы Российской империи 23 апреля 1906 г. - первая российская конституция: автореф. дис. ... канд. юрид. наук. М., 2001.

14. Концепция нового учебно-методического комплекса по отечественной истории. URL: rushistory.org

15. Бёрк Э. Письмо г-на Бёрка к члену национальной ассамблеи в ответ на некоторые возражения в отношении его книги о положении дел во Франции // Бёрк Э. Правление, политика и общество: сборник / пер. с англ. Л. Полякова. М., 2001. C. 415-416.

16. Конституция Российской Федерации. URL: base.garant.ru/10103000/1/\#5555 